\title{
Wybrane aspekty opieki pielęgniarskiej w opiece nad pacjentem w podeszłym wieku z przewlekłą obturacyjną chorobą płuc - studium przypadku
}

\author{
Selected Aspects of Nursing Care of Older Patients with Chronic Obstructive \\ Pulmonary Disease- Case Study
}

\section{Streszczenie}

Wstęp. POChP jest chorobą przewlekłą płuc o progresywnie wzrastającej liczbie zachorowań i śmiertelności. Charakteryzuje się postępującym i nieodwracalnym ograniczeniem przepływu powietrza przez drogi oddechowe. Wykazano, iż schorzenie to diagnozowane jest u blisko 8-10\% Europejczyków po 30 rż. Wraz z wiekiem istotnie statystycznie wzrasta występowanie chorób przewlekłych.

Prezentacja przypadku. Opis przypadku dotyczy pacjentki w wieku 65 lat chorującej na POChP. Obejmuje on także problemy pielęgnacyjne, jakie występują u chorej oraz interwencje, które powinna podjąć pielęgniarka, by zredukować bądź całkowicie wyeliminować zdiagnozowane i zaobserwowane problemy. Prezentowane studium przypadku jest opisem teoretycznym.

Dyskusja. POChP ze względu na swój przewlekły charakter i szerokie rozpowszechnienie uznawana jest za jeden z najistotniejszych problemów zdrowia publicznego. Częstotliwość zachorowań wzrasta wraz z wiekiem. Odnotowano, że szczyt zachorowań najczęściej występuję w szóstej dekadzie życia. Główną rolą pielęgniarki $\mathrm{w}$ opiece nad pacjentem $\mathrm{z}$ tą jednostką chorobową jest wykonywanie profesjonalnych czynności pielęgnacyjnych, leczniczych, rehabilitacyjnych i diagnostycznych. Istotny aspekt stanowi również edukacja, która powinna być przeprowadzana przez pielęgniarki w trakcie pobytu chorego na oddziale.

Wnioski. W obliczu pogorszającego się sukcesywnie funkcjonowania psychospołecznego osób starszych z POCHP warto byłoby się zastanowić nad wprowadzeniem przesiewowych badań w kierunku wczesnego wykrywania tej jednostki chorobowej np. w placówkach podstawowej opieki zdrowotnej. Należy także dążyć do wprowadzania licznych programów przeciwdziałających POCHP, a także uświadamiających społeczeństwo o identyfikowaniu POCHP z oddzielną jednostką chorobową, a nie utożsamianiu jej $\mathrm{z}$ naturalnym elementem procesu starzenia się.

\footnotetext{
Abstract:

Introduction. COPD is a chronic pulmonary progressively increasing the number of morbidity and mortality. It is characterized by progressive and irreversible airflow limitation by inhalation. It has been shown that the disease is diagnosed here it is nearly 8-10\% of Europeans after 30 years of age. As people age significantly increasing incidence of chronic diseases.
} 
Case Presentation. Case report refers to a patient at the age of 65 sufferers of COPD. It also includes nursing problems that occur in the patient and interventions that should take a nurse, to reduce or eliminate diagnosed and observed problems. The presented case study is a description of the theoretical.

Discussion. COPD because of its chronic nature and wide dissemination is considered one of the most important public health problems. The incidence increases with age. It was noted that the peak incidence occurs most often in the sixth decade of life. The main role of nurses in the care of patients with this disease entity is to perform professional tasks care, treatment, rehabilitation and diagnostics. A significant aspect is also education, which should be carried out by nurses during the patient's stay in the ward.

Conclusions. In the face of more and worse psychosocial functioning of older people with COPD it would be worthwhile to consider introduction of screening tests for the early detection of this disease, for example in primary care. It should also seek to introduce a number of programs to counter COPD, as well as public awareness of COPD identification of a separate entity, rather than equating it with a natural part of the aging process.

Słowa kluczowe: przewlekła obturacyjna choroba płuc, opieka pielęgniarska, osoby starsze, problemy pielęgnacyjne

Key words: Chronic obstructive pulmonary disease, nursing care, elderly people, nursing problems

\section{Wstęp}

Zmiany obserwowane w strukturze demograficznej społeczeństwa coraz częściej stają się tematem publicznej dyskusji. Proces starzenia się zarówno mieszkańców Polski, jak i pozostałych krajów Unii Europejskiej (UE) w ostatnim stuleciu przybrał miano intensywnego zjawiska globalnego [1]. W konsekwencji demograficzne starzenie się ludności Polski przyczynia się do systematycznego wzrostu odetka osób z przewlekłą obturacyjną chorobą płuc (POChP) [2]. Charakteryzuje się ona przewlekłym i trwałym zredukowaniem przepływu powietrza przez drogi oddechowe. Ze względu na swój przewlekły charakter i szerokie rozpowszechnienie uznawana jest za jeden z najistotniejszych problemów zdrowia publicznego [3]. Wykazano, że schorzenie to diagnozowane jest u blisko 8-10\% Europejczyków po 30 rż [4]. Wraz z wiekiem istotnie statystycznie wzrasta zachorowalność na POChP [5]. Patogeneza tego schorzenia jest wieloczynnikowa [6]. Odnosi się ona zarówno do aspektów genetycznych, jak i środowiskowych i obejmuje zapalenie (przewlekłe zapalenie oskrzeli), utratę powierzchni pęcherzyków płucnych oraz zniszczenie oskrzelików oddechowych [7]. Schorzenie to w znaczący sposób obniża jakość życia chorych. Ponadto niesie za sobą znaczące konsekwencje ekonomiczne odnoszące się do wysokich kosztów przewlekłego leczenia [8]. Współpraca interdyscyplinarnego zespołu medycznego z pacjentem i jego rodziną przyczynia się do poprawy stanu ogólnego chorego oraz zredukowania lęku wynikającego z obawy przed uduszeniem [9].

Celem pracy jest dokonanie analizy problemów pielęgnacyjnych w oparciu o informację na temat sylwetki psychofizycznej pacjenta z przewlekłą obturacyjną chorobą płuc w okresie zaostrzenia objawów choroby.

\section{Prezentacja przypadku}

Pani Zyta lat 65 przyjęta do Katedry i Kliniki Geriatrii dnia 22.03.2016r. w trybie nagłym z powodu zaostrzenia objawów POChP. Pacjentka skarży się na trudności w oddychaniu, nasilającą się duszność wysiłkową i kaszel z obfitym odkrztuszaniem plwociny. Pacjentka opanowana, spokojna. Zgłasza ogólne osłabienie, zmęczenie i ból w klatce piersiowej. U chorej 4 lata temu zdiagnozowano nadciśnienie tętnicze. $\mathrm{W}$ dniu przyjęcia wynik pomiaru ciśnienia tętniczego (RR) - 170/110 mmHg. Chora nie przyjmuje regularnie przepisanych leków 
hipotensyjnych i nie prowadzi systematycznie dzienniczka samokontroli. W chwili wywiadu zachowana orientacja auto- i allopsychiczna. Pacjentka chętnie bierze udział w rozmowie i odpowiada na wszelkie pytania oraz utrzymuje kontakt wzrokowy. Kobieta została zakwalifikowana do II kategorii opieki pielęgniarskiej. Chora wymaga niewielkiej pomocy przy poruszaniu się i czynnościach higienicznych. Obecnie nie zgłasza żadnych potrzeb. Stan higieniczny bardzo dobry, włosy i skóra czyste, brak zmian patologicznych oraz zasinienia powłok skórnych. Bielizna pościelowa i osobista czysta. Pacjentka w skali Douglas uzyskała 22 pkt., a w skali Glasgow 15 pkt. W dniu dzisiejszym nie występuje stan zagrożenia życia; parametry życiowe wynoszą:

- - Ciśnienie tętnicze: $120 / 80 \mathrm{~mm} \mathrm{Hg}$;

- $\quad$ Temperatura: $36,7^{0} \mathrm{C}$;

- - Tętno: 70 uderzeń/ min, równe i miarowe;

- - Oddech: 16/ min, wykonywany bez wysiłku, regularny.

Pani Halina jest rencistką, posiada wyższe wykształcenie. Przez blisko 35 lat pracowała w szkole jako nauczycielka języka polskiego. Chora mieszka wraz z mężem w bloku na pierwszym piętrze. Warunki mieszkaniowe ocenia jako bardzo dobre. Mąż codziennie odwiedza pacjentkę w szpitalu. Pani Halina również zwraca uwagę na fakt, iż strasznie szybko się męczy np. idąc do łazienki. Podczas duszności odczuwa silne zawroty głowy oraz ucisk w klatce piersiowej. Pacjentka skarży się na kłopoty z zasypianiem.

U Pani Haliny 6 miesięcy temu zdiagnozowano POChP i nadciśnienie tętniczne, na które choruje od 2012 roku. W rodzinie kobiety nikt nie choruje na nadciśnienie tętnicze i POChP. Dotychczas rzadko rozpoznawano u niej objawy zapalenia płuc bądź zapalenia oskrzeli. Z wywiadu wynika, że kaszel z przezroczystą i często trudną do odkrztuszenia plwociną utrzymuje się u pacjentki od blisko 2 lat przynajmniej 4 miesiące w roku. Od tygodnia pojawiły się dodatkowo silne duszności podczas wysiłku. Pacjentka skarży się na progresywne zmniejszanie się tolerancji na wysiłek fizyczny. Od 20 lat kobieta pali około 20 papierosów dziennie. W okresie hospitalizacji udało się ograniczyć znacznie liczbę wypalanych papierosów do 5 dziennie.

Kobieta dobrze radzi sobie w sytuacjach stresowych. Jest przyjaźnie nastawiona wobec personelu medycznego. Wykazuje również dużą świadomość swojego stanu zdrowia. Chora ma założone wkłucie dożylne.

Stan pacjentki w kolejnych dobach pobytu w szpitalu ulegał znacznej poprawie. Niemniej jednak utrzymywał się męczący kaszel. W czasie pobytu Pani Halina miała wykonywane następujące badania: morfologia krwi, spirometria, RTG klatki piersiowej.

\section{Plan opieki pielęgniarskiej wobec pacjentki w starszym wieku w przebiegu POCHP w dniu przyjęcia do szpitala}

\section{PROBLEM 1:}

Niepokój spowodowany hospitalizacją i procesem leczenia.

CEL:

Zniwelowanie lęku spowodowanego hospitalizacją.

DZIAŁANIA:

- Przeprowadzenie rozmowy z pacjentką na temat choroby,

- zapewnienie poczucia bezpieczeństwa,

- zapewnienie życzliwej, cichej i spokojnej atmosfery, 
- nawiązanie kontaktu emocjonalnego z pacjentką, zapoznanie się z jej potrzebami, dolegliwościami, problemami,

- zachowanie cierpliwości i spokoju podczas rozmowy,

- umożliwienie kontaktu z lekarzem,

- zapoznanie pacjentki z topografią i regulaminem oddziału,

- okazywanie zainteresowania ogólnym samopoczuciem pacjentki przez pielęgniarkę,

- angażowanie rodziny w procesie terapeutycznym.

OCENA:

Zniwelowano niepokój związany z hospitalizacją i procesem leczenia.

\section{PROBLEM 2:}

Trudności w oddychaniu z powodu zaostrzenia objawów POChP.

CEL:

Zmniejszenie duszności i uspokojenie pacjenta.

DZIAŁANIA:

- Czynny udział w tlenoterapii,

- częste wietrzenie pomieszczenia

- zachęcanie pacjentki i pomoc w przyjmowaniu pozycji wysokiej lub półwysokiej,

- monitorowanie podstawowych parametrów życiowych (tętno, oddech, ciśnienie tętnicze, temperatura ciała),

- udział w postępowaniu farmakologicznym na zlecenie lekarza.

OCENA:

Zredukowano duszność i lęk u pacjentki.

PROBLEM 3:

Zwiększone ryzyko wystąpienia powikłań nadciśnienia tętniczego (udar mózgu, zawał serca) spowodowane brakiem wiedzy na temat choroby i niefarmakologicznych metod leczenia

CEL:

Zmniejszenie ryzyka wystąpienia powikłań nadciśnienia tętniczego (udaru mózgu, zawału serca)

DZIAŁANIA:

- Dwukrotne przeprowadzenie 30-minutej pogadanki wprowadzającej do zagadnień oraz sprawdzającej poziom wiedzy pacjenta i jego rodziny na temat istoty choroby,

- wytłumaczenie pacjentce definicji i pojęć związanych z chorobą: ciśnienie skurczowe, ciśnienie rozkurczowe,

- przedstawienie pacjentce $\mathrm{w}$ formie grafiki zakresu prawidłowych wartości ciśnienia tętniczego,

- przekazanie pacjentce dzienniczka samokontroli - poinformowanie o regularnym wpisywaniu wartości ciśnienia tętniczego krwi do dzienniczka po rannym i wieczornym pomiarze,

- pomiar RR 2 razy dziennie (rano i wieczorem) oraz w przypadku wystąpienia takich dolegliwości jak silny ból głowy z zawrotami, ból w klatce piersiowej, duszność a także w przypadku złego samopoczucia,

- przedstawienie pacjentce prawidłowych technik pomiaru ciśnienia tętniczego aparatem elektronicznym:

- zwrócenie uwagi na 10-minutowy odpoczynek przed pomiarem RR, 
- wdrożenie do zasad właściwego zakładania mankietu do pomiaru RR (2-3 cm powyżej zgięcia łokciowego),

- zwrócenie pacjentce uwagi na unikanie picia kawy i palenia papierosów przed pomiarem,

- zwrócenie uwagi na konieczność podparcia kończyny na której mierzone jest ciśnienie tętnicze,

- zwrócenie uwagi, aby podczas pomiaru RR pacjentka nie rozmawiała (doprowadza to do zaburzeń w wynikach pomiaru),

- przeprowadzenie instruktażu pomiaru RR,

- trzykrotne przeprowadzenie 40-minutowej pogadanki skierowanej do pacjentki i jej syna na temat zasad diety w nadciśnieniu tętniczym:

- zalecenie ograniczenie ilości spożywanej soli o połowę,

- wskazanie na konieczność wykluczenia z diety produktów konserwowanych solą tj. wędzonych ryb, wędzonych wędlin, zółtych serów, kiszonych ogórków,

- zwrócenie pacjentce uwagi na to, aby soliła potrawy pod koniec gotowania lub tuż przed podaniem w celu utrzymania pożądanych walorów smakowych,

- zachęcenie do zastępowania soli innymi przyprawami: pieprzem, papryką, oregano, chrzanem, octem,

- zalecenie ograniczenia ilości spożywanych tłuszczów zwierzęcych,

- zapoznanie pacjentki z informacją na temat produktów zawierających znaczne ilości magnezu i potasu- wręczenie wykazu tych produktów,

- dwukrotne przeprowadzenie 20-minutowej pogadanki odnośnie sposobów relaksacji oraz racjonalnego wypoczynku (wizualizacja, nieforsująca gimnastyka, czytanie książek, słuchanie muzyki relaksacyjnej).

\section{OCENA:}

Nie wystąpiły objawy powikłań nadciśnienia tętniczego.

\section{PROBLEM 4:}

Zwiększone ryzyko nasilenia się objawów POCHP i nadciśnienia tętniczego z powodu palenia papierosów.

CEL:

Ograniczenie ilości wypalanych papierosów, zmniejszenie nasilenia objawów POCHP i normalizacja wartości RR

DZIAŁANIA:

- Przedstawienie pacjentce negatywnego wpływu palenia tytoniu na układ krążenia i układ oddechowy,

- ukazanie korzyści wynikających z zerwania z nałogiem (np. wyeliminowania czynnika ryzyka utraty zdrowia, ukazanie aspektów finansowych),

- przedstawione pacjentce niefarmakologicznych metod radzenia sobie $\mathrm{z}$ nałogiem np. ssanie owoców goździków,

- poproszenie znajomych pacjentki, aby nie częstowali jej papierosami,

- w przypadku, gdy pacjentka poczuje chęć zapalenia papierosa zachęcenie do spożycia owoców lub niskokalorycznej przekąski, żucie gumy, gryzienie pestek słonecznika lub dyni, 
- zaproponowanie pacjentce po konsultacji z lekarzem korzystania z farmakologicznych metod walki z nałogiem: stosowanie gumy do żucia, plastry, pastylek do ssania, aerozolu do stosowania w jamie ustnej

OCENA:

Pacjentka ograniczyła ilość wypalanych papierosów, nieznacznie zmniejszyło się nasilenia objawów POCHP, wartości RR utrzymują się w granicach wysokiej normy

\section{PROBLEM 5:}

Uciążliwy kaszel z odkrztuszaniem zalegającej wydzieliny w drzewie oskrzelowym.

CEL:

Ułatwienie odkrztuszania zalegającej wydzieliny, poprawa samopoczucia pacjentki.

DZIAŁANIA:

- Nauczanie pacjentki efektywnego odkrztuszania nagromadzonej wydzieliny w drogach oddechowych,

- prowadzenie gimnastyki oddechowej, ćwiczeń wspomagających efektywny kaszel (głęboki wdech i 3 krótkie wydechy),

- stosowanie drenażu złożeniowego,

- oklepywanie klatki piersiowej w celu usunięcia zalegającej wydzieliny,

- ułożenie pacjentki w pozycji wysokiej lub półwysokiej,

- przypominanie chorej o konieczności nawadniania organizmu, co również ułatwi ewakuację wydzieliny z dróg oddechowych,

- zapewnienie pacjentce ligniny i worka na skażone odpady, co zapobiega krzyżowemu zakażeniu i ułatwia usuwanie zakażonej wydzieliny,

- przepłukiwanie jamy ustnej po odkrztuszaniu wydzieliny,

- przygotowanie odpowiedniego mikroklimatu pomieszczenia, w którym znajduje się pacjentka; częste wietrzenie pomieszczenia, w celu dostarczenia świeżego powietrza,

- udział w farmakoterapii poprzez stosowanie leków rozrzedzających wydzielinę i wykrztuśnych na zlecenie lekarza.

OCENA:

Pacjentka efektywniej odkrztusza wydzielinę, jej samopoczucie uległo poprawie.

\section{PROBLEM 6:}

Lęk wynikający z toczącej się choroby oraz obawa przez znacznym pogorszeniem się jakości życia

CEL:

Redukcja lęku, pomoc w akceptacji choroby

DZIAŁANIA:

- Przekazanie pacjentce i jej rodzinie wiedzy na temat jednostki chorobowej jaką jest POChP, jej przyczynach oraz objawach,

- przyjmowanie postawy otwartości i gotowości do wysłuchania, wsparcie emocjonalne pacjentki poprzez inicjowanie kontaktu,

- okazywanie serdeczności, cierpliwości, zainteresowania i troski,

- omówienie zasad prawidłowego stylu życia i prowadzenia aktywności fizycznej (unikanie bezczynności, codzienna aktywność, unikanie nadmiernego wysiłku, który pogłębiałby niedobór tlenu, unikanie stresu, nauka zwalczania bezsenności),

- utrzymanie u pacjentki postawy odpowiedzialności za własne zdrowie, 
- w sytuacji nasilenia się objawów POChP zalecenie chorej niezwłocznej wizyty u lekarza. OCENA:

Zredukowano lęk wynikający z obawy przed znacznym pogorszeniem się jakości życia.

\section{Dyskusja}

POChP ze względu na swój przewlekły charakter i szerokie rozpowszechnienie uznawana jest za jeden $\mathrm{z}$ najistotniejszych problemów zdrowia publicznego. Wraz $\mathrm{z}$ wiekiem istotnie statystycznie wzrasta występowanie chorób przewlekłych. U około $45 \%$ osób starszych rozpoznaje się choroby układu oddechowego. Zajmują one trzecie miejsce na liście najczęstszych chorób seniorów po schorzeniach układu sercowo-naczyniowego (75\% osób starszych), i chorobach układu ruchu (65\% populacji osób w podeszłym wieku) [5].

W ogólnopolskim badaniu PolSenior populację badanych stanowiło 4979 osób w wieku $79,4 \pm 8,69$ lat $(48,4 \%$ kobiet, $n=2412$ oraz 51,6\% mężczyzn, $n=2567)$. Grupa kontrolna obejmowała 716 respondentów w wieku 55-59 lat. Dokonano oceny natężenia występowania schorzeń układu oddechowego na podstawie kwestionariuszowego badania medycznego. Respondenci odpowiadali na pytanie dotyczące zdiagnozowania u nich choroby układu oddechowego, takiej jak: astma oskrzelowa, rozedma płuc, POChP, przewlekłe zapalenie oskrzeli. Wśród 17,9\% (n=886) badanej populacji zdiagnozowano schorzenia układu oddechowego. Dla porównania u osób w wieku 55-59 lat występowanie tych chorób odnotowano na poziomie blisko $11 \%$. Wykazano istotne statystycznie zależności pomiędzy wiekiem a natężeniem występowania schorzeń układu oddechowego. Wśród populacji osób w wieku 80-84 lat zaobserwowano najczęstsze rozpowszechnienie chorób na poziomie 19,9\% ( $n=157)$. U osób po 90 rż. schorzenia układu oddechowego odnotowano u 19,8\% (n=151) respondentów [2].

Z kolei w doniesieniach Bednarka i współautorów POChP zdiagnozowano u około 9,3\% osób powyżej 40 rż [10]. W badaniach przeprowadzonych przez Siatkowską i współpracowników populację badanych stanowiło 1026 osób $(52,1 \%$ kobiet, $n=535$ oraz 47,9\% mężczyzn, $\mathrm{n}=491$ ) w wieku 18-83 lata. POChP zdiagnozowano wśród 62 respondentów w wieku 58,5 $\pm 13,8$ lat, co stanowi 6,04\% ogółu badanej populacji. Natomiast wśród 61,3\% (n=38) badanych wykryto stadium I POChP, czyli jej łagodną postać. Drugie stadium choroby zdiagnozowano wśród 35,5\% (n=22) respondentów, natomiast III stadium u 3,2\% (n=2) [11].

$\mathrm{W}$ przedstawionym $\mathrm{w}$ pracy opisie przypadku chorobę zdiagnozowano $\mathrm{w}$ wieku 65 lat. Kaszel z przezroczystą i często trudną do odkrztuszenia plwociną utrzymuje się u chorej przez blisko 2 lata, przynajmniej 4 miesiące w roku. Można zatem założyć, że choroba ta pojawiła się już w wieku 63 lat.

Wiodącym czynnikiem ryzyka POChP jest palenie papierosów. Wykazano, iż blisko 33\% populacji osób w Polsce pali papierosy [12]. Według badań wśród pacjentów, u których zdiagnozowano POChP blisko 85-90\% przypadków odnosi się do palaczy czynnych. Palacze bierni również są narażeni na rozwój POChP, jednak w mniejszym nasileniu niż osoby palące czynnie [13]. Według badań Przybylskiej-Kuć i współautorów wśród 67 osób w wieku 24-80 lat (średnia 52 lata) odnotowano, iż najczęstszym powikłaniem nikotynizmu jest rak płuc $(94,03 \%)$. Kolejno wymieniono raka krtani $(76,12 \%)$ a na trzecim miejscu wraz z zawałem serca $(56,72 \%)$ zakwalifikowano astmę/POChP z wynikiem 56,72\% [12]. W badaniach przeprowadzonych przez Siatkowską i współpracowników aktualni i byli palacze stanowili 90,3\% pacjentów ze zdiagnozowaną POChP [11].

Pacjentka, która została przedstawiona w opisie przypadku jest uzależniona od nikotyny - pali papierosy od 20 lat. Ograniczenie palenia tytoniu w ciągu dnia w pozytywny sposób 
wpłynęło na zmniejszenie epizodów duszności. Wobec chorej podjęto edukację zdrowotną na temat uzależnienia od nikotyny, negatywnym wpływie tytoniozależności na stan zdrowia. Wskazano metody zerwania z nałogiem.

\section{Podsumowanie}

Celem pracy było scharakteryzowanie jednostki chorobowej, którą jest POChP oraz przedstawienie problemów pacjentów $\mathrm{w}$ jej przebiegu. W pracy podkreślono zadania pielęgniarki w opiece nad seniorem w przebiegu POChP, która ze względu na swój przewlekły charakter i szerokie rozpowszechnienie uznawana jest za jeden z najistotniejszych problemów zdrowia publicznego. $\mathrm{W}$ odniesieniu do danych epidemiologicznych $\mathrm{z}$ pewnością można stwierdzić, iż częstotliwość zachorowań na POCHP wzrasta wraz z zawansowaniem wieku pacjentów. Odnotowano, że szczyt zachorowań najczęściej występuje w szóstej dekadzie życia.

Według GOLD istotnym aspektem w procesie leczenia POCHP jest zaprzestanie palenia tytoniu. Odnotowano, iż ten czynnik ma największy wpływ na naturalny przebieg choroby. Niemniej istotna jest systematycznie stosowana farmakoterapia. Doraźnie wykorzystuje się krótko- i szybkodziałające leki rozszerzające oskrzela, cholinolityczne (bromek ipratropium), beta2-mimetyki (fenoterol) bądź mieszankę obu opisanych leków. Działania terapeutyczne $\mathrm{z}$ wykorzystaniem tlenu stosuje się $\mathrm{w}$ późnym okresie choroby bądź podczas jej zaostrzenia. Głównym celem tlenoterapii jest przeciwdziałanie powikłaniom sercowo-naczyniowym wynikającym z niebezpieczeństwa rozwoju serca płucnego. W leczeniu POChP istotną rolę odgrywa także zanieczyszczenie powietrza atmosferycznego a szczególnie zanieczyszczenie powietrza w zamkniętych miejscach (wynikające ze spalania paliw opartych na biomasie) oraz oddziaływanie szkodliwych czynników $\mathrm{w}$ powietrzu związanych $\mathrm{z}$ wykonywaną pracą. Wymienione czynniki sprzyjają powstawaniu przewlekłego stanu zapalnego, który odgrywa istotną rolę w patogenezie POChP.

$\mathrm{W}$ opiece nad osobami $\mathrm{z}$ POChP istotne jest uświadomienie pacjentom, iż jest to schorzenie o charakterze przewlekłym i wymaga systematycznej kontroli ze strony interdyscyplinarnego zespołu terapeutycznego. Głównym zadaniem pielęgniarki staje się edukacja chorego i jego rodziny na temat eliminacji czynników ryzyka, które wpływają na przebieg choroby. Niezbędne jest również przekazanie pacjentowi informacji na temat zasad samodzielnego, systematycznego stosowania leków. Ważną rolę odgrywa także edukacja pacjentów na temat zaprzestania palenia papierosów.

Znaczącą rolę w przebiegu choroby przewlekłej odgrywa wsparcie ze strony personelu medycznego oraz rodziny. W obliczu pogarszającego się sukcesywnie funkcjonowania psychospołecznego osób starszych z POCHP warto rozważyć wprowadzenie przesiewowych badań w kierunku wczesnego wykrywania choroby na poziomie podstawowej opieki zdrowotnej.

\section{Bibliografia/Bibliography:}

1. Markiewicz E., Skawina I. Polityczna orientacja państw w zakresie społeczeństw starzejących się. Gerontologia Polska. 2015;1:34-40.

2. Mossakowska M., Więcek A., Błędowski P. Aspekty medyczne, psychologiczne, socjologiczne i ekonomiczne starzenia się ludzie w Polsce W: Błędowski P. (red.) Starzenie się jako problem społeczny. Perspektywy demograficznego starzenia się ludności Polski do roku 2035. PolSenior. Termedia. 2012:123-136. 
3. Celli B.R., Wand M. Standars for the diagnosis and treatment of patients with COPD: a Sumary of the ATS/RRS position paper. European Respiratory Journal and Committee Members. 2004;23:932-946.

4. Mannino D.M. Chronic obstructive pulmonary disease: definition and epidemiology. Respiratory Care 2003;48:1185-1191.

5. Kozak-Szkopek E. Ocena kliniczna chorego w podeszłym wieku z przewlekłą obturacyjną chorobą płuc. Gerontologia Polska. 2007;15(3):61-68.

6. Kara M., Kirkil G., Kalemci S. Differential Expression of MicroRNAs in Chronic Obstructive Pulmonary Diseas, Advances in Clinical and Experimental Medicine. 2016;25(1):21-26.

7. Mizumura K., Cloonan S.M., Nakahira K., i in. 2014. Mitophagy-dependent necroptosis contributes to the pathogenesis of COPD. Journal of Clinical Investigation. 2014;124(9):3987-4003.

8. Kwon H.Y., Kim E. Factors contributing to quality of life in COPD patients in South Korea. International Journal Of Chronic Obstructive Pulmonary Disease. 2016;11:103-109.

9. Vestbo J. COPD: definition and phenotypes. Clinics in Chest Medicine. 2014;35(1)1-6.

10. Bednarek M., Maciejewski J., Woźniak M., i in. Prevalence, severity and underdiagnosis of COPD in the primary care setting. Thorax. 2008;63:402-407.

11. Siatkowska H., Kozielski J., Ziora D. Chorzy na przewlekłą oburacyjną chorobę płuc w praktyce lekarza podstawowej opieki zdrowotne. Pneumonologia i Alergologia Polska. 2010;78(2):112-120.

12. Przybylska-Kuć S., Bartoszek E., Dec M., i in. Świadomość pacjentów dotycząca powikłań związanych z paleniem papierosów. Family Medicine \& Primary Care Review. 2014;16(2)153-154.

13. Grzelewska-Rzymowska I. Standardy leczenia przewlekłej obturacyjnej choroby płuc. Alergia Astma Immunologia. 2006;11(4):188-194. 